\title{
Appendix K
}

\section{The Berne Convention Implementation Act of $1988^{1}$}

\section{Sec.1 - Short Title and References to Title 17, United States Code.}

(a) Short Title. - This Act, may be cited as the "Berne Convention Implementation Act of 1988".

(b) References to Title 17, United States Code. - Whenever in this Act an amendment or repeal is expressed in terms of an amendment to or a repeal of a section or other provision, the reference shall be considered to be made to a section or other provision of title 17, United States Code.

\section{Sec. 2 - Declarations.}

The Congress makes the following declarations:

(1) The Convention for the Protection of Literary and Artistic Works, signed at Berne, Switzerland, on September 9, 1886, and all acts, protocols, and revisions thereto (hereafter in this Act referred to as the "Berne Convention") are not self-executing under the Constitution and laws of the United States.

(2) The obligations of the United States under the Berne Convention may be performed only pursuant to appropriate domestic law.

(3) The amendments made by this Act, together with the law as it exists on the date of the enactment of this Act, satisfy the obligations of the United States in adhering to the Berne Convention and no further rights or interests shall be recognized or created for that purpose.

\section{Sec. 3 - Construction of the Berne Convention.}

(a) Relationship with Domestic Law. - The provisions of the Berne Convention -

(1) shall be given effect under title 17, as amended by this Act, and any other relevant provision of Federal or State law, including the common law; and

(2) shall not be enforceable in any action brought pursuant to the provisions of the Berne Convention itself.

(b) Certain Rights Not Affected. - The provisions of the Berne Convention, the adherence of the United States thereto, and satisfaction of United States obligations thereunder, do not expand or reduce any right of an author of a work, whether claimed under Federal, State, or the common law- 
(1) to claim authorship of the work; or

(2) to object to any distortion, mutilation, or other modification of, or other derogatory action in relation to, the work, that would prejudice the author's honor or reputation.

\section{Sec. 12 - Works in the public domain.}

Title 17, United States Code, as amended by this Act, does not provide copyright protection for any work that is in the public domain in the United States.

\section{Sec. 13 - Effective date: effect on pending cases.}

(a) Effective Date. - This Act and the amendments made by this Act take effect on the date on which the Berne Convention (as defined in section 101 of title 17, United States Code) enters into force with respect to the United States. ${ }^{2}$

(b) Effect on Pending Cases. - Any cause of action arising under title 17, United States Code, before the effective date of this Act shall be governed by the provisions of such title as in effect when the cause of action arose.

\section{Appendix K - Notes}

1. This appendix consists of provisions of the Berne Convention Implementation Act of 1988, Pub. L. No. 100-568, 102 Stat. 2853, that do not amend title 17 of the United States Code.

2. The Berne Convention entered into force in the United States on March 1, 1989. 